\title{
Generations Y and Z in The WorkPlace: Perception of TeamWork
}

\author{
Jiří Kutlák \\ University of West Bohemia, Faculty of Economics, \\ Department of Business Economics and Management, \\ Univerzitní 22, 30614 Pilsen, Czech Republic \\ e-mail: kutlak@kpm.zcu.cz
}

\begin{abstract}
The article presents a literary review focused on the definition of generations and perception of teamwork and communication by two chosen generations - Y (Millennials) and Z. The analysis of teamwork was subsequently carried out on the basis of a questionnaire survey conducted in 2019 on a sample of 266 respondents in the Czech Republic. The questionnaire survey was supplemented by a content analysis of company job adverts from 2016-2019 in a total of 667 analyzed adverts. One research hypothesis and two research questions were formulated. Pearson's Chi-square Independence Test was used to evaluate the hypotheses. Based on data analysis, no dependence between the selected generations and teamwork preferences was found. The data imply that respondents prefer to work in teams with people they know personally. From the content analysis of the job fair catalogs, the receding tendencies in reporting on the possibilities of teamwork in the workplaces are evident.
\end{abstract}

\section{Keywords}

Team work; Millenials; Generation Y; Generation Z; Communication.

\section{Introduction}

Teamwork is one of a series of management tools and methods which is expected to create more efficient, productive and creative organizational units. The introduction of teamwork entails, in addition to the traditional challenges of establishing team roles etc., the challenge in the form of acceptance by the employees themselves [1]. Even though this is a very subjective attitude of individuals themselves, it is possible to observe long-term trends in the approach to teamwork and cooperation. These tendencies can be observed on the basis of attitudes of individual age generations. The generations whose representatives are economically active (15-64 years old) include the generation of Baby Boomers, X, Y and Z [2]. The analysis of teamwork in this article focuses on the two youngest generations, Generation $Y$ and Generation Z.

As can be seen from many characteristics and definitions [2], [6], [7], the age classification of individual generations is very dependent on the selected authors and specific territories (and associated historical events). The accurate age classification also alludes to the fact that it is not possible to specify by the year to which generation an individual belongs. Especially in a situation where generations are defined in addition to the yearly classification also by the specific characteristics of the members of the generations. It is therefore possible to encounter individuals who, according to the age classification, fall into a different generation than according to characteristics, personal attitudes and demands. Nevertheless, mainly for the uniform methodology of evaluation of the research, the age span classification was determined as follows:

- Baby Boomers (1946-1964) 
- Generation X (1965-1982)

- Generation Y (1983-2000)

- Generation Z (2001-2010) [2], [6], [7], [8], [9].

According to a research by the personnel company ManpowerGroup [3], the share of the two youngest economically active generations will be almost $60 \%$ of the world's labor force in 2020. However, this share will be about 41\% (to 2022) in the Czech Republic. In both cases it is almost a half of the workforce whose opinions, attitudes and values will largely influence the work environment and processes [4]. In addition to the positions of the Generation $Y$ and $\mathrm{Z}$, it is also necessary to compare changes between these generations. These changes can be represented by a full change of values as well as a partial change. For example, money (wages, salaries, etc.) is still the biggest motivator despite the fact that there are intergenerational differences in perception (security vs. gaining respect, ways of satisfying desires). Nevertheless, literature mentions reducing intergenerational differences, especially among young generations [5].

\section{$1 \quad$ Perception of Teamwork by Generations}

Changes in attitude towards teamwork are evident across all generations. According to Bencsik [10], there is a development from understanding teamwork as a natural environment in international working groups (Generation $X$ ) through confidence in success as a result of teamwork (Generation Y) to understanding teamwork at the virtual level (Generation Z). A similar conclusion is also found in the Adecco study [11]. The results of the study show that the youngest Generation $\mathrm{Z}$ prefers work alone and does not like to engage in teamwork tasks and collaboration. This fact is a consequence of the already mentioned cooperation on the virtual level. Similar outcomes also result from the Half"s research [12], according to which $2 / 3$ of the respondents prefer collaboration in a small team. The research was focused on American and Canadian students (representatives of Generation Z).

Different results were obtained in Iorgulescu's research [13], which carried out a survey on about 150 Romanian students (Generation Z). According to the conclusions, less than a half prefer work in large offices and teams. On the contrary, 1/3 of the respondents would choose a separate office and $10 \%$ of the respondents could imagine cooperation in a small team. The results are supported or influenced by the fact that $44.9 \%$ of respondents would like to work in a large international corporation. Among other things, the expectations of Generation $\mathrm{Z}$ that are needed for a successful career have also been explored. It was the ability to work in a team with a score of 4.28 (scale 1-5) that was placed fourth. Respondents consider it more important than the knowledge of 2-3 foreign languages or the knowledge of project management. The importance of teamwork is also confirmed by Bencsik's research [10], in which a positive relationship to teamwork is evaluated on the Likert scale (1-5) of 3.38. This fact ranks it among the top six characteristics expected from both Generation $Y$ and Generation $\mathrm{Z}$ representatives.

The issue of the size of teams and offices is also analyzed by Miller [14]. Based on the research among US teenagers, the study concludes that the Millennials generally prefer a collaborative environment. In fact, many companies have removed separate offices for greater interaction and collaborative development. On the other hand, it is also mentioned that with the onset of Generation $\mathrm{Z}$ - on the basis of its characteristics - individualism and competitive nature begin to rise. The result is a return from open-plan offices back to a more individualistic and competitive environment. This return is also confirmed by a study by Puiu [15], according to which almost $95 \%$ of Generation $\mathrm{Z}$ representatives prefer individual over group approach. At the same time, the results of the research show that almost $40 \%$ of 
respondents prefer "ability to work in a team" as one of the most important things (most, $50.5 \%$, prefer "problem solving").

Despite the fact that the representatives of the Generation $\mathrm{Z}$ tend to be more independent, it does not mean that they cannot imagine teamwork. There is a retreat from large teams towards smaller teams where the individuals meet with long-familiar colleagues. This fact is also supported by the results of the study by Csehpapp et al. [16], according to which cheerful teams are required by $95 \%$ of Generation $\mathrm{Z}$ respondents (the second highest priority). Similar results have also been obtained from the ManpowerGroup's study [3], according to which $80 \%$ of the Generation Y respondents (the fourth highest priority) want to work with a team of great colleagues. Inclination for teamwork among representatives of the Generation $\mathrm{Y}$ is also confirmed by Oblinger and Oblinger [7].

As noted above, the different approaches of a selected generation's representatives often differ according to the locations of research. Different results were obtained from studies investigating Romanian or American Generation Z [12], [13]. It is the geographical aspect that has a great impact on the research of the characteristics of individual generations [5]. Havlíček et al. [17] apply international research to a total of 600 representatives of the Generation $\mathrm{Z}$ in 7 European countries. One of the researched issues is what kind of abilities the respondent prefers. Below is presented a list of country-specific "team skills" results:

- Cyprus: $20 \%$ of respondents,

- Czech Republic: $66 \%$ of respondents,

- Hungary: $30 \%$ of respondents,

- Poland: $7 \%$ of respondents,

- Portugal: $31 \%$ of respondents,

- Spain: $40 \%$ of respondents,

- Ukraine: $23 \%$ of respondents [17].

Of the total of 11 possibilities, the ability of teamwork was most often placed on 2. - 4 . position. The same research included an analysis of a preferred size of a work team. The most frequent answer across all of the countries was working in a small team. Furthermore, the addressed representatives of the Generation $\mathrm{Z}$ preferred the mostly separately as a response. Conversely, about 5-10\% of the respondents chosen the answer work with a large team or the answer completely separately. [17]

Equally important issue correlated with teamwork is also communication and information sharing in a workplace or in teams. According to Miller [14], the Generation Z representatives prefer personal communication (43\%), followed by text messages (24\%), telephone (14\%), email (11\%) and social media (8\%). Moreover, Bejtkovsky et al. [2] also mention that e-mail is one of the most important means of communication for Generation Y. It is evident that with the onset of the youngest Generation $\mathrm{Z}$, there is a return to personal communication, which was crucial for older generations $-X$ and Baby Boomers. Unlike the older generations, both generations ( $\mathrm{Z}$ and Millennials) prefer communication only when needed, and it should be done more quickly and easily [10].

\section{$2 \quad$ Research Methodology}

The aim of the article is to analyze and outline teamwork issues in relation to selected generations, specifically to $\mathrm{Y}$ (Millenials) and Generation $\mathrm{Z}$. Through the use of databases (Web of Science; EBSCO database) the current publishing activities related to the theme of teamwork in relation to generations are analyzed and compared. These domestic and world 
studies produced good information backup for the creation of the questionnaire survey and content analysis as a primary research of the article.

\subsection{Questionnaire Survey}

The questionnaire survey was carried out at the beginning of 2018 among representatives of the selected Generations Y and Z, who were divided according to their years of birth (see yearly anchoring in the introduction of the work). An anonymous questionnaire survey was applied among students of the Faculty of Economics of the University of West Bohemia in Pilsen. In order to avoid homogeneity of the sample as much as possible, students of the first year of bachelor study program were selected as representatives of the Generation Z (modus 19 years). On the contrary, the students of the last fifth year of the follow-up master's study program were addressed as representatives of the Generation Y (modus 25 years). Given the fact that most students of the last year have at least partial work experience, this has also an impact on the possible undesirable increase in homogeneity of the selected sample of students. Nevertheless, it is necessary to mention that the homogeneity of the sample is one of the limitations of the research.

The questionnaire was distributed among the students using the electronic form Google documents. In addition to socio-demographic questions, the questionnaire consisted, inter alia, of the following questions: Do you prefer to work in a team or alone? (closed answers option); What kind of communication would you prefer / prefer in the work environment? (open answers option). For cleaning and processing data for further analysis, the Excel program (filters and Contingency tables) was used.

Based on the theoretical background, the following research hypothesis and research question were evaluated:

The research hypothesis: There is a statistically significant dependence between the attitudes to teamwork on the basis of membership of the selected generation ( $Y$ and $Z$ ) in the Czech Republic.

The research question (2): What correlation can be observed in communication medium preferences for selected Generations $Y$ and $Z$ in a workplace?

\subsubsection{Structure of the Sample}

A total of 266 respondents participated in the questionnaire survey. The distribution according to age and gender is shown in Table 1 below. Representation is distributed almost evenly, both in terms of the various generations and gender.

Tab. 1: The age structure of the questionnaire survey

\begin{tabular}{|l|c|c|c|c|c|}
\hline \multirow{2}{*}{ Generation } & \multirow{2}{*}{ Age span } & \multicolumn{2}{|c|}{ Sex } & \multirow{2}{*}{ Absolute frequency } & \multirow{2}{*}{ Relative frequency } \\
\cline { 3 - 6 } & & Female & Male & & \\
\hline Generation Y & $1983-2000$ & 83 & 69 & 152 & $57 \%$ \\
\hline Generation Z & $2001-2010$ & 56 & 58 & 114 & $43 \%$ \\
\hline Total & - & $\mathbf{1 3 9}$ & $\mathbf{1 2 7}$ & $\mathbf{2 6 6}$ & $\mathbf{1 0 0 \%}$ \\
\hline
\end{tabular}

Source: Own questionnaire survey, 2019

\subsection{Content Analysis}

The second part of primary research was the content analysis. The aim of the content analysis was to identify references to teamwork in job fair advertisements. Due to the fact that the labor market is currently gradually being filled by representatives of Generation Z, the job fair catalogs of the Job Fair at the University of West Bohemia in Pilsen was subject to content 
analysis. The results of the analysis can indicate a possible gradual transition in the perception of teamwork (in accordance with Generation Z) in job fair catalogs that are intended for students. To evaluate the results of the content analysis, the following research question was set.

The research question (1): What trends in relation to teamwork can be seen in company job fair advertisements?

Using content analysis, 667 published job advertisements were processed. All business advertisements for the years 2016-2019 were analyzed regardless of their focus (all fields were represented in the advertisements without distinction and there is no distortion of results due to the influence of specific job requirements for certain job positions). Four years are analyzed, namely the years 2016, 2017, 2018 and 2019. In those years (chronologically) 149, 165, 185 and 168 job adverts are explored. The fields of job adverts were the following: Applied Sciences, Economics, Electric Power Industry, Design, Humanities, IT, Law, Construction, Civil Engineering and IT.

Regarding the size of analyzed companies, according to the methodology of the European Union [21], the largest number of companies was represented by large companies (> 250 employees), followed by medium-sized companies (50-250 employees) and small companies (10-49 employees). For example, in 2017 and 2018, this ratio was $76 \%$ for a large business, $23 \%$ for a medium business and $1 \%$ for a small business. The dominance of large companies is mainly due to their financial possibilities to participate in job fairs.

\subsection{Chi-Square Independence Test}

Descriptive statistics tools, such as average, share etc. are used to evaluate the research. To evaluate other hypotheses, the results are subjected to the Pearson's Chi-square independence testing. The online statistical tool of the Social Science Statistics is used for the evaluation.

The Pearson's Chi-square test is based on the idea of comparing the observed frequencies and the so-called expected frequencies (calculated on the assumption of validity) of individual combinations of random variables $\mathrm{X}$ and $\mathrm{Y}$. The following statistic has for the null hypothesis of independence chi-square probability distribution with parameter $(r-1) \mathrm{x}(s-1)$, that is, the following applies $\chi^{2} \sim \chi^{2}(r-1) \times(s-1)[18]$.

$$
\chi^{2}=\sum_{i} \sum_{j} \frac{\left(n_{i j}-e_{i j}\right)^{2}}{e_{i j}}
$$

where:

$X^{2}-$ test criterion value

$n$ - range selection

$e_{i j}$ - expected frequency

$n_{i j}$ - observed frequency

$r$ - number of contingency table rows

$s$ - number of contingency table columns [18].

The basic conditions for using this test include that the individual observations summarized in the Contingency table are independent, so each element of the sample is included in only one cell of the table. Additionally, at least $80 \%$ of the Contingency table cells have an expected frequency greater than 5 , and all table cells (100\% of the cells) have an expected frequency greater than 2. This assumption is related to the asymptotic properties of statistics [19]. 
To fulfill the aim of this article one research hypothesis and two research questions were set. In this chapter, the results of the statistical processing of the data collated from the research are presented.

The research hypothesis: There is a statistically significant dependence between the attitudes to teamwork on the basis of membership of the selected generation ( $Y$ and $Z$ ) in the Czech Republic.

The research hypothesis, which verifies the validity of the theoretical background, focuses on the analysis of the relationship between attitude toward teamwork and generations. Respondents answered the question whether they prefer rather work in a team or alone. There were three choices: Alone; In the team (with close people); In the team (even with strangers). The absolute frequency of individual responses can be seen in Table 2 below. In both analyzed generations it is possible to observe that respondents prefer to work in a team with people they know personally. Working alone or in a team with unknown people / colleagues is then preferred at a similar level.

Tab. 2: Teamwork preferences (percentages indicate the relative share related to the given generation)

\begin{tabular}{|l|l|l|l|}
\hline & Of one's own & Team (with close people) & Team (even with strangers) \\
\hline Generation Y & $34(22 \%)$ & $85(56 \%)$ & $33(22 \%)$ \\
\hline Generation Z & $23(20 \%)$ & $64(56 \%)$ & $27(24 \%)$ \\
\hline Total & 57 & 149 & 60 \\
\hline
\end{tabular}

Source: Own questionnaire survey, 2019

The obtained data were further subjected to the test of independence for which the following hypotheses have been determined.

- $\boldsymbol{H}_{0}$ : There is no relationship between the preferences of teamwork and given generation.

- $\boldsymbol{H}_{A}$ : There is a relationship between the preferences of teamwork and given generation.

In other words, the alternative hypothesis claims that there is no difference between generations and their relationship to teamwork.

Tab. 3: Verification of hypothesis by Pearson's Chi-square test

$\mathrm{H}_{1}$ : There is a statistically significant dependence between the attitudes to the teamwork on the basis of membership of the selected generation ( $Y$ and $Z$ ) in the Czech Republic.

\begin{tabular}{|l|l|}
\hline The statistical method & Pearson's Chi-square test \\
\hline Chi-square & 0.259 \\
\hline Degrees of freedom (d.f.) & 2 \\
\hline Probability ( $p$-value) & 0.878 \\
\hline
\end{tabular}

Source: Own questionnaire survey, 2019

Based on the Pearson's Chi-square test of independence, which shows the $p$-value of $87.8 \%$, we do not reject the null hypothesis at the 5\% significance level. The resulting value shows a very strong independence of data, which can be interpreted as follows. The distribution of individual responses is not dependent on the generation of respondents. At the same time, on the basis of the independence test, we reject research hypothesis, which assumed the significant dependence of the variables examined. 
If the data from the questionnaire survey is filtered according to the current work experience, the following outputs are obtained. The results are very similar for students. $P$-value test of independence reaches $62.2 \%($ Chi-square $=0.9486$, d.f. $=2)$. It indicates a slightly lower but still very strong independence statistically examined data.

On the contrary, when analyzing the data of respondents with work experience, the p-value of the Pearson's Chi-square test is $10.4 \%($ Chi-square $=4.5236$; d.f. $=2)$. Despite the fact that we still reject the alternative hypothesis at the $5 \%$ significance level, the results are diametrically different and cannot be marked as statistically significant.

The research question (1): What trends in relation to teamwork can be seen in job adverts?

The research question aims to analyze what changes have been made to company job adverts over the past 4 years in publishing on teamwork opportunities in the workplace. The review of the studies shows that the generation of the Millennials perceive teamwork as one of the core competencies and skills they expect in their working lives. They also expect teamwork in the workplace.

Slightly different tendencies can be observed in the Generation $\mathrm{Z}$, in which a shift towards individualism becomes apparent. However, it is necessary to mention that the Job Fair at the University of West Bohemia in Pilsen focuses on recent graduates - representatives of Generation Y. The oldest representatives of Generation $\mathrm{Z}$ are 19 years old and are therefore not the main target group of the analyzed job adverts [2], [6], [7], [8], and [9].

The company job fairs have been subject to a content analysis that focuses on two groups of terms. The first group contains specific terms that are directly related to teamwork (teamwork; teamwork collaboration; team player; teamwork ability; international teams; team spirit; expert teams and team communication). These terms are often found in the requirements for a candidate or under the heading "What we offer". The second group contains terms that are related to teamwork rather indirectly (join our team; our team is looking forward to you; our team of experienced colleagues is waiting for you etc.).

Tab. 4: Content analysis of job fair catalogs focusing on teamwork (number of companies)

\begin{tabular}{|l|l|l|l|l|}
\hline Year & Direct mention & Indirect mention & Mentions overall & Number of job adverts \\
\hline 2016 & 32 & 25 & 57 & 149 \\
\hline 2017 & 32 & 34 & 66 & 165 \\
\hline 2018 & 34 & 29 & 63 & 185 \\
\hline 2019 & 25 & 32 & 57 & 168 \\
\hline
\end{tabular}

Source: Own content analysis, 2019

As shown in Figure 1 below, the direct mentions of teamwork in job adverts are reduced by about two percentage points each year. Thus, companies are increasingly less inform about the possibilities or capabilities of teamwork and collaboration. Currently (2019), the term teamwork appears in only one of seven job adverts. If there is a focus on indirect mentions, no clear tendency can be observed. The results tend to oscillate around a relative value of $18 \%$. The overall relative comparison of mentions to teamwork in job fair catalogs shows that there is a gradual decline, driven mainly by a steady decline in direct mentions. 


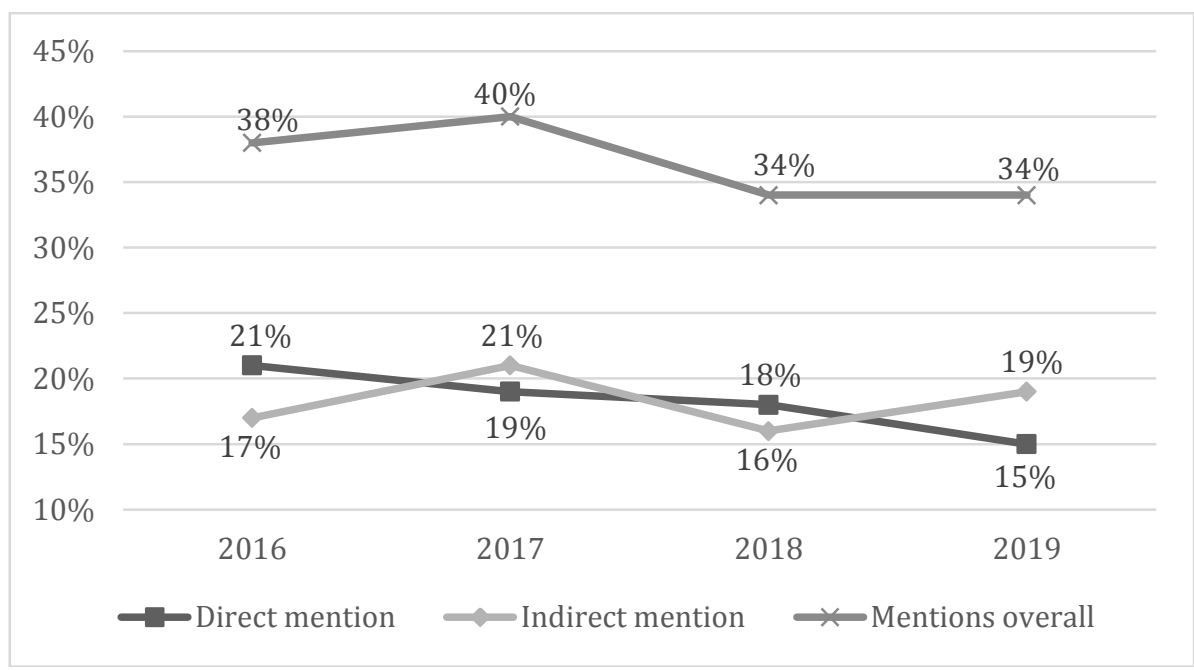

Source: Own content analysis, 2019

Fig. 1: Relative shares of results of the content analysis (\%), 2016-2019

The research question (2): What relation can be observed in communication medium preferences for selected Generations $Y$ and $Z$ in a workplace?

According to the results of the questionnaire survey shown in Table 5, it is clear that personal contact is the most preferred form of communication for both analyzed generations particularly among Generation Z. Conversely, e-mail communication is more preferred by the Millennials. Telephone communication (text messages and calls) prefer both generations at a similar level. The results also show a gradual diversion of the youngest generation from social networks (e.g. Facebook) and a move to communication through applications that can be used on various media (PC, mobile phone).

Tab. 5: Selection of communication media

\begin{tabular}{|l|r|r|r|r|}
\hline & \multicolumn{2}{|c|}{ Generation Y } & \multicolumn{2}{|c|}{ Generation Z } \\
\hline Personal & 135 & $44 \%$ & 105 & $50 \%$ \\
\hline E-mail & 74 & $24 \%$ & 40 & $19 \%$ \\
\hline Phone & 51 & $16 \%$ & 34 & $16 \%$ \\
\hline Social network & 26 & $8 \%$ & 10 & $5 \%$ \\
\hline Apps (e.g. WhatsApp) & 24 & $8 \%$ & 22 & $10 \%$ \\
\hline Total & 310 & $100 \%$ & 211 & $100 \%$ \\
\hline
\end{tabular}

Source: Own questionnaire survey, 2019

When comparing the results of the survey with the results of the Miller study (United States) [14], there is a consensus on the distribution of the resulting data. The results of the theoretical research are also confirmed by the fact that Generation Y prefers the e-mail communication or that Generation $\mathrm{Z}$ is gradually strengthening its preferences in personal communication [2].

\section{Discussion}

This article focuses on the issue of age groups, i.e. generations. The aim was to examine teamwork issues in relation to selected generations, specifically to $\mathrm{Y}$ (Millenials) and Generation Z. It is these two generations that will strengthen their labor market influence over the coming years. Specifically, they will account for about $40-60 \%$ of the workforce [3], [4]. On the basis of the theoretical background, the researched issue was introduced and the chosen generations were defined according to the age spans. The analysis of studies implies 
that representatives of the older Generation $\mathrm{Y}$ have more positive relationship to the teamwork. They also support the so-called open space, which enable faster flow of information and encourage collaboration. On the other hand, Generation Z representatives show a gradual return to individualism, which is also typical for the older generations ( $\mathrm{X}$ and Baby Boomers) [20].

The analysis also shows that various studies come to contradictory results. This difference is mainly due to the geographic point of view, where the greatest differences can be seen intercontinental (Central Europe vs. North America etc.) [12], [13]. However, according to Havlíček et. al [17], it is possible to identify certain differences also across the Europe. The results of the analysis shows that the ability in the form of teamwork and cooperation is rated by representatives of both generations as one of the most important. According to research hypotheses validation, the representatives of both generations rather prefer to work in a small team with people they know personally. These results correlate directly with the results of international research by Havlíček et al. [17], which also came to the conclusion that respondents prefer teamwork in the team with people they know personally.

Primary research in this article is represented by the questionnaire survey and content analysis. Based on an analysis of the summary questionnaire survey conducted by Pearson's Chi-square independence test, it is not possible to statistically confirm the dependence between teamwork preference and selected generations. According to the results, there is a discrepancy between the results of the questionnaire survey and the theoretical framework of the article, where differences between the preferences of individual generations were recorded on the basis of a secondary data analysis [13], [14], and [16]. A weaker dependence (near the $10 \%$ significance level) can be confirmed on data obtained from respondents with work experience. This fact may indicate that the difference in preferences of generations may be reflected only in the professional life of individuals. In the meantime (e.g. in the student years) inter-generational differences may be wiped out.

The content analysis of the job fair catalogs focused on the analysis of the issue from the perspective of employers. According to 667 analyzed job adverts for the period 2016-2019, it is possible to confirm the downward trend in references to the possibilities or abilities of teamwork in the workplace. Direct mention (see definition above) about the teamwork occurred in only $18 \%$ and $15 \%$ job adverts in the last two years. The decline can be driven by the gradually rising Generation Z, which is typical of a return to the individualism [14], [15]. For the verification or falsification of Generation $\mathrm{Z}$ influence, it will be necessary to continue the content analysis in the coming years. Another option is to extend the subject of analysis to other job advertisements (other job fairs). However, it should be noted that a large proportion of advertising companies operate throughout the Czech Republic, and therefore job advertisements often coincide across various job fairs.

As regards communication in the workplace, which strongly correlates with teamwork, both generations prefer a personal form. These results are also supported by the mentioned studies [2], [14]. An important finding for the setting of personnel processes and the type of communication in the workplace is that with the advent of the Generation Z, despite their considerable individualism, there is a return to personal form of communication. This was typical especially for older generations [14], [15], [16]. Representatives of Generation Y, compared with representatives of Generation Z, prefer more e-mail communication and communication on social networks. Conversely, more representatives from Generation $\mathrm{Z}$ prefer communication via applications like the WhatsApp and others. 
The research contains several limitations. First, despite its size, the research sample cannot confirm the trends of generations examined in the Czech Republic. However, the results may indicate certain patterns of behavior, which can then be verified in further research. The representativeness of the research sample is also a limitation. This was mainly due to financial possibilities limited to students of the University of West Bohemia, which had an impact on the homogeneity of respondents. They differed by about 6 years (on the range of examined Generations $\mathrm{Y}$ and Z), which may affect the similarity in the perception of teamwork.

\section{Conclusion}

The present article illustrates the results of research that is focused on the perceptions of the teamwork among selected Generations Y and Z. Based on the research results, it can be argued that there are no significant differences in perception and attitude of teamwork by selected generations. Although it should be noted that the validity of the hypothesis is justified only in the context of the presented research, which cannot be considered representative.

Nevertheless, the study highlights several thought-provoking issues. For example, the study shows that, when verifying the independence of data aimed only at individuals with work experience, the results of the research indicate a significantly stronger dependence of perception of teamwork across generations. This may support the idea that the perceptions and attitudes of generations in relation to the working environment are created only after gaining certain job opportunities. At the same time, on the basis of content analysis of job fair advertisements, there is presented the fact that over the past 4 years companies have not reacted in the perception of teamwork in their advertisements for the coming-in of the new Generation $\mathrm{Z}$ on the labor market. These results are valid with the results of a questionnaire survey, which did not confirm the difference between the examined generations in the perception of team cooperation. However, it is precisely the gradual coming-in of Generation $\mathrm{Z}$ into the labor market that can change the attitudes and beliefs that businesses will have to accept in their business processes.

\section{Acknowledgements}

This article was created within the project SGS-2017-013 "Use of new approaches in management and in marketing".

\section{Literature}

[1] BUSSINESINFO: Týmová práce. [online]. 2010. [accessed 2019-05-15]. Available from WWW: https://Www.businessinfo.cz/cs/clanky/tymova-prace-2831.html

[2] BEJTKOVSKÝ, J.: The Employees of Baby Boomers Generation, Generation X, Generation $\mathrm{Y}$ and Generation $\mathrm{Z}$ in Selected Czech Corporations as Conceivers of Development and Competitiveness in their Corporation. Journal of Competitiveness. 2016, 8(4), 105-123. DOI:10.7441/joc.2016.04.07

[3] MANPOWER: Mileniálové a kariéra: vize 2020. [online]. 2016. Available from WWW: https://www.manpower.cz/manpower/cs/milenialove-a-kariera-vize-2020/

[4] ČSÚ: Věkové složení populace $\check{C} R$. [online]. 2018. [accessed 2019-05-15]. Available from WWW: https://wWw.czso.cz/staticke/animgraf/cz/

[5] KUTLÁK, J.: Vícegenerační ř́zení na pracovišti: Vliv na personální procesy. Trendy v Podnikání-Business Trends. 2018, 8(4). DOI: 10.24132/jbt.2018.8.4.84_95 
[6] TAPSCOTT, D.: Grown up digital: How the net generation is changing your world. McGraw-Hill, New York, NY, 2009. ISBN-13: 978-0071508636.

[7] OBLINGER, D.; OBLINGER, J.: Is it age or IT: first steps towards understanding the net generation. In D. Oblinger \& J. Oblinger (Eds) Educating the Net generation. EDUCAUSE, Boulder, CO. [online]. 2005. [accessed 2019-05-15]. Available from WWW: https://www.educause.edu/research-and-publications/books/educating-netgeneration

[8] MARTIN, C. A.; TUlGAN, B.: Managing the Generation Mix. $2^{\text {nd }}$ Edition. HRD Press, Amherst, MA, 2002. ISBN-13: 978-0874259414.

[9] LIFFREING, I.: Forget millennials, Gen Alpha is here (mostly). [online]. 2018. [accessed 2019-05-15]. Available from WWW: https://digiday.com/marketing/forgetmillennials-gen-alpha/

[10] BENCSIK, A.; HORVÁTH-CSIKÓS, G.; JUHÁSZ, T.: Y and Z Generations at Workplaces. Journal of Competitiveness. 2016, 6(3), 90-106. DOI: $\underline{10.7441 / \text { joc.2016.03.06 }}$

[11] ADECOO. Generation $Z$ vs. Millennials. [online]. 2015. [accessed 2019-05-15]. Available from WWW: http://pages.adeccousa.com/rs/107-IXF-539/images/generationz-vs-millennials.pdf

[12] HALF, R.: The Secrets to Hiring and Managing Gen Z. [online]. 2015. [accessed 201905-15]. Available from WWW: https://www.roberthalf.com/research-andinsights/workplace-research/the-secrets-to-hiring-and-managing-gen-Z

[13] IORGULESCU, M.-C.: Generation Z and its perception of work. CrossCultural Management Journal. 2016, 1, 47-54. [online]. [accessed 2019-05-15]. Available from WWW: https://econpapers.repec.org/article/cmjjournl/y_3a2016_3ai_3a9_3ap_3a47$\underline{54 . h t m}$

[14] MILLER, J.: A 16-Year-Old Explains 10 Things You Need to Know About Generation $Z$. [online]. 2018. [accessed 2019-05-15]. Available from WWW: https://www.shrm.org/hr-today/news/hr-magazine/1118/pages/a-16-year-old-explains10-things-you-need-to-know-about-generation-z.aspx

[15] PUIU, S.: Generation Z - an educational and managerial perspective. Young Economists Journal / Revista Tinerilor Economisti. 2017, 14(29), 62-72.

[16] CSEH-PAPP, I.; VARGA, E.; SZABÓ, K.; SZIRA, Z.; Hajós, L.: The appearance of a new generation on the labour market. International Journal of Engineering Tome. (XV), 123-130. [online]. 2017. [accessed 2019-05-15]. Available from WWW http://annals.fih.upt.ro/pdf-full/2017/ANNALS-2017-1-19.pdf

[17] HAVlíČEK, J.; DÖMEOVÁ, L.; HLAVATÝ, R.: Gen Z in the Workplace: Expectations, Communication and Relationships. In: Efficiency and Responsibility in Education. Prague, 2018. Available from WW: https://www.researchgate.net/publication/325756609_Gen_Z_in_the_workplace_Expect ations_communication_and_relationships

[18] HENDL, J.: Přehled statistických metod zpracováni dat: Analýza a metaanalýza dat. Portál, Praha, 2012. ISBN: 978-80-262-0200-4. 
[19] INSTITUT BIOSTATISTIKY A ANALÝZ MASARYKOVY UNIVERSITY: Testováni nezávislosti (Pearsonův chi-kvadrát test). [online]. 2019. [accessed 2019-0515]. Available from WWW http://portal.matematickabiologie.cz/index.php?pg=aplikovana-analyza-klinickych-abiologickych-dat--analyza-a-management-dat-pro-zdravotnicke-obory--testovanihypotez-o-kvalitativnich-promennych--analyza-kontingencnich-tabulek--testovaninezavislosti-pearsonuv-chi-kvadrat-test

[20] WIEDMER, T.: Generations Do Differ: Best Practices in Leading Traditionalists, Boomers, and Generations X, Y, and Z. Delta Kappa Gamma Bulletin. 2015. 82(1) 51.

[21] CZECHINVEST: Definice malého a středního podnikatele. [online]. 2014. [accessed 2019-02-04]. Available from WWW: https://www.czechinvest.org/cz/Sluzby-pro-malea-stredni-podnikatele/Chcete-dotace/OPPI/Radce/Definice-maleho-a-strednihopodnikatele 


\section{GENERACE Y A Z NA PRACOVIŠTI: VNÍMÁNÍ TÝMOVÉ PRÁCE}

Článek předkládá literární přehled, který je zaměřen na vymezení generací Y (Millennials) a $\mathrm{Z}$ a jejich vnímání týmové práce a komunikace. Analýza týmové práce byla následně prováděna na základě dotazníkového šttření uskutečněného $\mathrm{v}$ roce 2018 na vzorku 266 respondentů na území České republiky. Dotazníkové šetření bylo doplněno obsahovou analýzou veletržních firemních inzerátů $\mathrm{z}$ let 2016-2019 v celkovém počtu 667 analyzovaných inzerátů. Byla formulována jedna výzkumná hypotéza a dvě výzkumné otázky. Pro vyhodnocení hypotéz byl využit Pearsonův chí-kvadrát test nezávislosti. Na základě analýzy dat nebyla zjištěna závislost mezi vybranými generacemi a preferencí týmové spolupráce. $Z$ dat dále vyplývá, že respondenti upřednostňují spíše práci v týmech $\mathrm{s}$ lidmi, které osobně znají. $Z$ obsahové analýzy veletržních katalogů je pak patrná ustupující tendence v referování o možnostech týmové práce na pracovištích.

\section{DiE GENERATIONEN Y UND Z AM ARBEITSPLATZ: WAHRNEHMUNG DER TEAMARBEIT}

Dieser Beitrag legt einen literarischen Überblick vor, welcher auf die Definition der Generationen Y (Millennials) und Z sowie auf deren Wahrnehmung von Teamarbeit und Kommunikation ausgerichtet ist. Die Analyse der Teamarbeit wurde anschließend auf Grundlage einer Fragebogenaktion durchgeführt, welche im Jahre 2018 am Muster 266 der Befragten auf dem Gebiet der Tschechischen Republik realisiert wurde. Die Fragebogenuntersuchung wurde durch eine umfangreiche Analyse von Firmenmesseinseraten aus den Jahren 2016-2019 ergänzt. Die gesamte Anzahl der Inserate beträgt 667. Es wurden eine Forschungshypothese und zwei Forschungsfragen formuliert. Bei der Auswertung der Hypothesen kam Pearsons Chi-Quadrat-Test zur Anwendung. Auf Grundlage der Datenanalyse wurde keine gegenseitige Abhängigkeit zwischen den ausgewählten Generationen und der Präferenz der Zusammenarbeit im Team festgestellt. Aus den Daten geht weiter hervor, dass die Befragten eher Teamarbeit mit persönlich Bekannten bevorzugen. Aus der inhaltlichen Analyse der Messekataloge wird eine rückläufige Tendenz im Referieren über die Möglichkeiten der Teamarbeit an den Arbeitsplätzen ersichtlich.

\section{POKOLENIE Y I Z NA STANOWISKU PRACY: POSTRZEGANIE PRACY ZESPOŁOWEJ}

Niniejszy artykuł przedstawia przegląd literatury, określający pokolenie Y (Millennials) i Z oraz ich postrzeganie pracy zespołowej i komunikacji. Analizę pracy zespołowej przeprowadzono w oparciu o badania ankietowe zrealizowane w 2018 roku na próbce 266 respondentów na terenie Republiki Czeskiej. Badania ankietowe uzupełniono przedmiotową analizą firmowych ogłoszeń o pracę z lat 2016-2019, przy czym łącznie przeanalizowano 667 ogłoszeń. Sformułowano jedną hipotezę badawczą oraz dwa pytania badawcze. W celu oceny hipotezy wykorzystano test niezależności chi-kwadrat Pearsona. Na podstawie analizy danych nie stwierdzono zależności pomiędzy wybranymi pokoleniami a preferowaniem współpracy zespołowej. Ponadto $\mathrm{z}$ danych wynika, że respondenci bardziej wolą pracę $\mathrm{w}$ zespole z ludźmi, których osobiście znają. $Z$ analizy przedmiotu katalogów firmowych wynika zaś widoczna znikająca tendencja prezentowania możliwości pracy zespołowej na stanowiskach pracy. 